\title{
Application of Agricultural Waste as Heterogeneous Catalysts for Biodiesel Production
}

\author{
Haris Mahmood Khan ${ }^{1, *}$, Tanveer Iqbal ${ }^{1}$, Saima Yasin ${ }^{1}$, Chaudhry Haider Ali ${ }^{1}$, Muhammad Mujtaba Abbas ${ }^{2, *(D,}$ \\ Muhammad Asif Jamil 1 1D, Abrar Hussain ${ }^{3}$, Manzoore Elahi M. Soudagar ${ }^{2}$ (D) \\ and Muhammad Muhitur Rahman $4, *$ D
}

1 Department of Chemical, Polymer and Composite Materials Engineering, University of Engineering \& Technology, Lahore (New Campus), Lahore 54890, Pakistan; tanveer@uet.edu.pk (T.I.); drsaima@uet.edu.pk (S.Y.); haiderali@uet.edu.pk (C.H.A.); majamil@uet.edu.pk (M.A.J.)

2 Center for Energy Science, Department of Mechanical Engineering, University of Malaya, Kuala Lumpur 50603, Malaysia; me.soudagar@gmail.com

3 Department of Mechanical and Industrial Engineering, Tallinn University of Technology, Ehitajate Tee 5, 12616 Tallinn, Estonia; Abhuss@taltech.ee

4 Department of Civil and Environmental Engineering, College of Engineering, King Faisal University, Al-Ahsa 31982, Saudi Arabia

* Correspondence: hariskhan@uet.edu.pk (H.M.K.); m.mujtaba@uet.edu.pk (M.M.A.); mrahman@kfu.edu.sa (M.M.R.)

check for updates

Citation: Khan, H.M.; Iqbal, T.; Yasin, S.; Ali, C.H.; Abbas, M.M.; Jamil, M.A.; Hussain, A.; M. Soudagar, M.E.; Rahman, M.M. Application of Agricultural Waste as Heterogeneous Catalysts for Biodiesel Production. Catalysts 2021, 11, 1215. https:// doi.org/10.3390/catal11101215

Academic Editor: Consuelo Alvarez-Galvan

Received: 21 September 2021

Accepted: 4 October 2021

Published: 9 October 2021

Publisher's Note: MDPI stays neutral with regard to jurisdictional claims in published maps and institutional affiliations.

Copyright: (c) 2021 by the authors. Licensee MDPI, Basel, Switzerland. This article is an open access article distributed under the terms and conditions of the Creative Commons Attribution (CC BY) license (https:/ / creativecommons.org/licenses/by/ $4.0 /)$.

\begin{abstract}
In this modern era, it has become essential to transform waste materials into valuables because of their excessive availability, along with achieving the targets of environmental protocols and waste management policies. With a growing population, the utilization and consumption of agricultural products have been increased extensively. In addition, it has increased the probability of agricultural waste generation. Waste produced from agricultural sources is considered as a viable source for synthesizing economical and ecofriendly catalysts and suitable ways for its disposal are sought. This study is targeted at agricultural waste-derived heterogeneous catalysts, which have been effectively employed for biodiesel generation. The types of agricultural waste, catalyst synthesis techniques, recent literature stated for agricultural waste-derived catalysts to produce biodiesel, the elemental composition and catalytic activity of agricultural waste ashes, the effect of reaction parameters to maximize biodiesel yield and catalyst reusability have been discussed. This work concludes that catalysts derived from agricultural waste are efficient in transesterification reaction, and they are easy to produce, and are cheap and ecofriendly. Moreover, this study encourages researchers to see the options for unexplored agricultural waste, which can be potentially converted into useful materials
\end{abstract}

Keywords: agricultural waste; heterogeneous catalysts; biodiesel; yield

\section{Introduction}

Global energy consumption, particularly, from petroleum sources has increased owing to the fast growth in the worldwide population, urbanization, and industrialization; hence, it has triggered to a raise in emissions levels causing global warming and antagonistic medical issues. The threat of fossil fuel depletion in the upcoming years has motivated the scientific community to explore alternative renewable energy resources to avoid a situation of extreme energy crisis, along with environmental protection purposes. Therefore, the quest for renewable and ecofriendly fuels has become mandatory and is the need of the hour. In the past two decades, vegetable oil-derived methyl esters have gained popularity as a promising substitute for conventional diesel and is termed biodiesel [1-4].

Biodiesel is a renewable fuel possessing similar properties to diesel fuel, such as combustion, flow, chemical composition, etc., and therefore, its combination with mineral diesel can be effectively utilized in diesel engines, directly or with some modifications $[5,6]$. 
In addition, the absence of sulfur and aromatic components in biodiesel contributes to a higher burning efficiency, higher cetane number, and better lubricity characteristics, along with a reduction in emissions of particulate matter $\left(\mathrm{NO}_{x}, \mathrm{CO}\right.$, etc.) [7]. Therefore, biodiesel combustion could be more environmentally friendly compared to conventional diesel. Regrettably, there exists extensive complications associated with the commercial viability of biodiesel owing to food vs. fuel competition and its high price. The utilization of inedible oils, waste oils, and cost-effective catalysts would facilitate reducing biodiesel production costs $[8,9]$. Numerous efforts have been made to generate biodiesel from variety of feedstocks [10], while the exploration of cost-effective efficient catalysts is being examined for upscaled biodiesel production.

Transesterification is considered to be an effective technique for transforming oils or fats into biodiesel using homogeneous catalysts [11]. Despite displaying a good catalytic performance in transesterification reactions, homogeneous catalysts are naturally corrosive for equipment and their difficult removal from the mixture implies further operational expenses. In addition, purification and water washing stages are required to achieve standard quality fuel, and results in high production costs $[10,12]$. Quite the opposite, the usage of solid/heterogeneous catalysts to produce biodiesel has been shown to be feasible and effective due to their simple separation, being less corrosive and their environmentally friendly nature [13]. These catalysts are effectively reusable and therefore, enhance production outcomes. There exists an extensive number of applications of heterogeneous (acid/base) catalysts in the literature. The utilization of a base catalyst in transesterification has been evaluated as being relatively noticeable owing to the issues of the high temperature and prolonged reaction times required for the acid catalyzed process of transesterification [14]. Consequently, the situation caused researchers to explore other types of heterogeneous base catalysts, such as calcined hydrotalcite, metal oxides, anion exchange resins, and supported alkali metals [15-18].

It would be a excellent opportunity if heterogeneous catalysts could be synthesized from abundantly available waste materials, such as agricultural waste, to cut down on the catalyst costs associated with biodiesel production. Therefore, the usage of waste materials for catalyst generation could make the system more economical and more eco-friendly, in addition to producing the aimed product. Catalyst synthesis from waste materials has been increasingly reported recently because of the excessive availability of waste resources, as well as their disposal issues. The characteristics of the obtained catalysts is notably affected by the type of waste origin, and consequently the catalytic products for a particular use are often made from an analogous category of materials [16].

The expansion of soil for agricultural production and technological development for the green revolution are major aspects responsible for increased agricultural production [19,20]. Twenty-four million tons of food are produced by the agricultural sector around the globe, which also causes about health-related issues for the environment if their waste disposal is not appropriate [19]. Although food is a necessity obtained from agriculture, its environmental effects are also obvious. The effective ways of tackling agricultural solid wastes are needed to avoid the ill effects of agriculture on marine life, human health, and overall ecosystems [21]. For instance, if this waste is left unhandled or burnt directly, it may create air, water, and land pollution.

The prioritization of food and energy production for the increasing population has been mandated by global leaders and the population is expected to increase to about 10 billion by 2050 . However, this target should be accomplished with zero solid waste, lower emissions, along with minimum fossil fuel consumption [22,23]. Moreover, food generation for an increasing population, industrial requirements, and animal feed are predicted to be included in the increased agricultural production. Agricultural activities involve the generation of solid waste at each step, depending on the category of product required, processing methods, and purpose of usage. The major producer of agricultural solid waste is farming activities, and may also encompass other activities that are connected with farming and the food chain. The purpose of this study was to focus on the literature 
reported on agricultural waste-based heterogeneous catalysts that are effectively used for biodiesel generation. The types of agricultural waste, catalyst synthesis techniques, recent literature on agricultural waste-derived catalysts to produce biodiesel, the elemental composition of agricultural waste ashes, the effect of reaction parameters in maximizing biodiesel yield, as well as catalyst reusability have been elaborated. The work concludes that catalysts derived from agricultural waste are efficient in transesterification reactions, easy to produce, cheap, and ecofriendly. Moreover, this study can encourage researchers to see the possible uses of unexplored agricultural waste, which can be potentially transformed into valuable materials. With respect to future prospects, alternate applications of these agricultural waste-based catalysts can also be explored based on the data reviewed in this article.

\section{Types of Agro-Industrial Wastes}

\subsection{Agricultural Residues}

Agro-industrial waste is categorized into two types, agricultural residues and industrial residues, as indicated in Figure 1 [24].

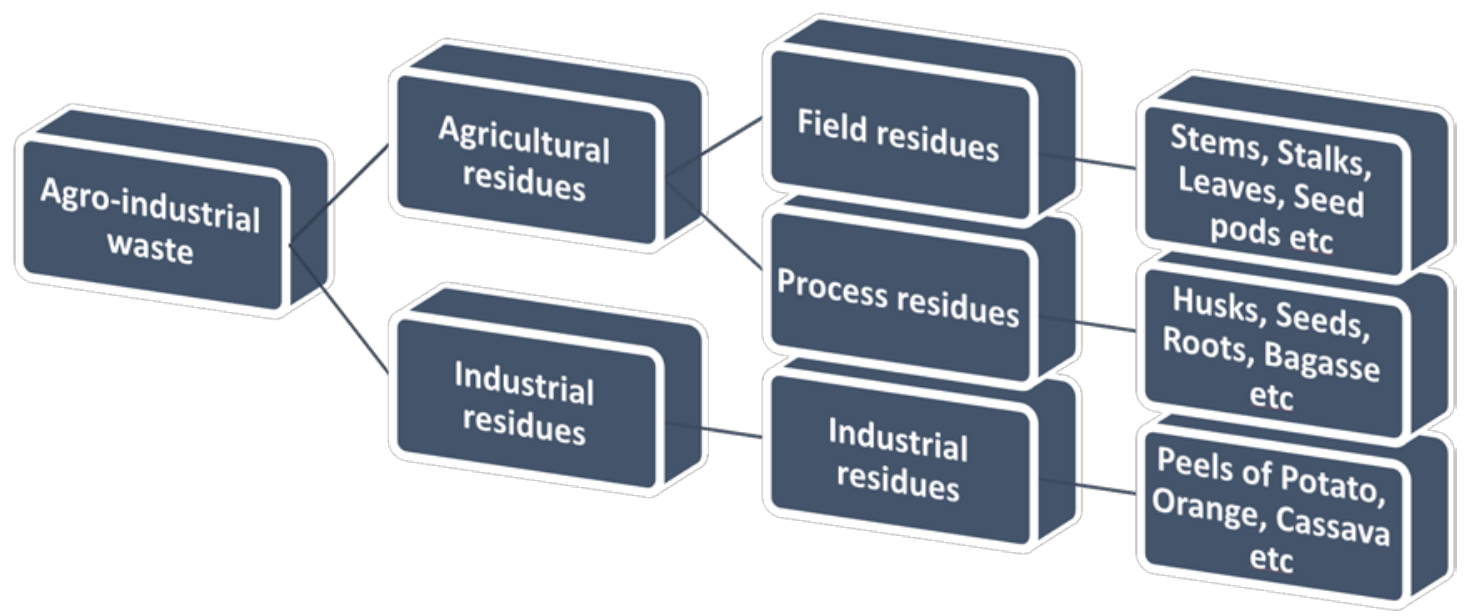

Figure 1. Categorization of agro-industrial waste.

Agriculture residues are written off as field residues and process residues; after harvesting, the waste that remains in the field are termed field residues, which consists of stalks, leaf stems, and seed pods etc whereas, the process residues are the remains up to the point where the crop is transformed into another valued resource. These remains are comprised of leaf straw, stem, husks, bagasse, stalk shell peels, roots, etc.

\subsection{Industrial Wastes}

Food processing manufacturers, such as potato chip, juice, sweets, and fruit industries, generate huge quantities of organic residues each year that can be used as diverse energy sources. For instance, fruit peels, coffee pulp, and husks are generated as waste by the juice industry, the coffee industry, and cereal industry, respectively. Each year, billions of tons of food industry waste are generated globally, such as peels from different fruits, sugarcane bagasse, wheat straw residues, rice straw remains, etc. For instance, in the 1990s, rice straw and wheat straw residues were estimated to have values of 673.3 and 709.2 million metric tons globally [25]. These huge quantities of waste, generated each year, require legal methods for proper management and potential utilization to lessen the ecological burden.

\section{Waste to Valuables}

The global trend of transforming waste into valuable materials for various applications is gaining popularity owing to environmental concerns. Recently, the literature has reported various commercial heterogeneous catalysts for transforming different feedstocks into 
biodiesel, including calcium, magnesium, and aluminum-based catalysts. Although some of these heterogeneous catalysts are found to be highly effective, they are still considered unsustainable for producing biodiesel owing to the labor-intensive methods involved in their synthesis. In addition, these catalysts are non-renewable, sourced commercial catalysts and therefore their usage creates disposal issues and ecological concerns. On the other hand, agricultural waste-based catalysts, such as banana and orange peels, cocoa pod husk ash, Musa balbisiana peel ash, leave ash, banana trunk ash, coconut husk and ash, are non-toxic, cheap, non-corrosive, and are readily available. These catalysts are shown to be effective, biodegradable, and a feasible way of managing agricultural waste by means of biodiesel production. In addition, agricultural waste shows diverse uses and applications, particularly in the production of biogas, biofuels, animal feed, mushroom, biofertilizers, and for other chemicals [26].

\section{Synthesis Techniques for Catalysts Produced from Agricultural Wastes}

Numerous methods have been utilized in the published works for the alteration of agricultural waste into catalysts. These techniques require careful selection to attain desired catalytic potentials. The synthesis methodology for transforming agricultural waste into catalysts entails the collection and sorting of different agricultural wastes from different places, and their delivery to scientific laboratories for further processing. After collection and sorting, waste is cleaned to detach impurities and then dried in an oven or in sunlight. Oven drying is quicker and has a controlled drying rate, but it is energy intensive. Sundrying is inexpensive but time-consuming and the solid waste is vulnerable to impurities. After completion of the drying process, the material is milled to an appropriate size using meshes. Figure 2 shows the general procedure for the extraction of solid catalysts from waste resources. After that, the powdered material is exposed to a high-temperature heat treatment (calcination) for a specific time. The performance of the catalyst is greatly controlled by the temperature and time of calcination; therefore, this requires careful selection of both parameters. In addition to calcination, other modification techniques exist to upgrade the catalytic properties and these are indicated in Figure 3. Catalysts can either be directly utilized after milling and sieving or some modification methods, such as calcination, wet impregnation, physical mixing, co-precipitation, hydration, can be applied for the improvement of catalytic properties [27].

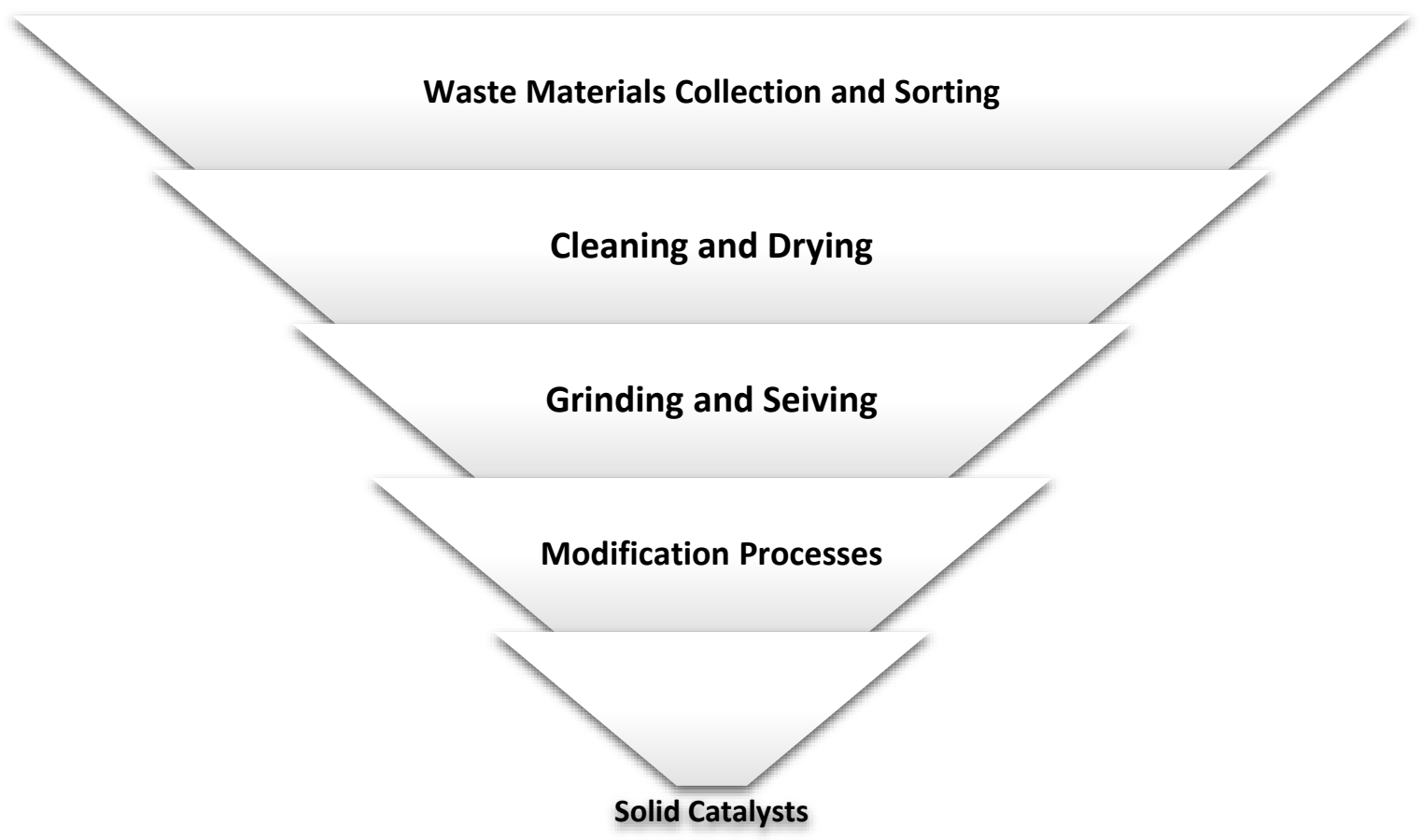

Figure 2. Generic synthesis method for transforming agricultural wastes into a solid catalysts. 


\section{Calcination-hydration-dehydration}

The basic active sites and catalytic surface area can be enhanced by exposing the heat-treated material to hydration and drying. The resulting product is treated with demineralized water and refluxed at a suitable temperature, speed and time. Afterward, the mixture is filtered and dessicated in an oven and later calcination is carried out to get pure oxides with improved catalytic traits

\section{Bifunctional Modification Method}

Is a recent technique for the effectice catalyst generation. The catalysts having both basic and acidic properties are generated for better catalytic activity

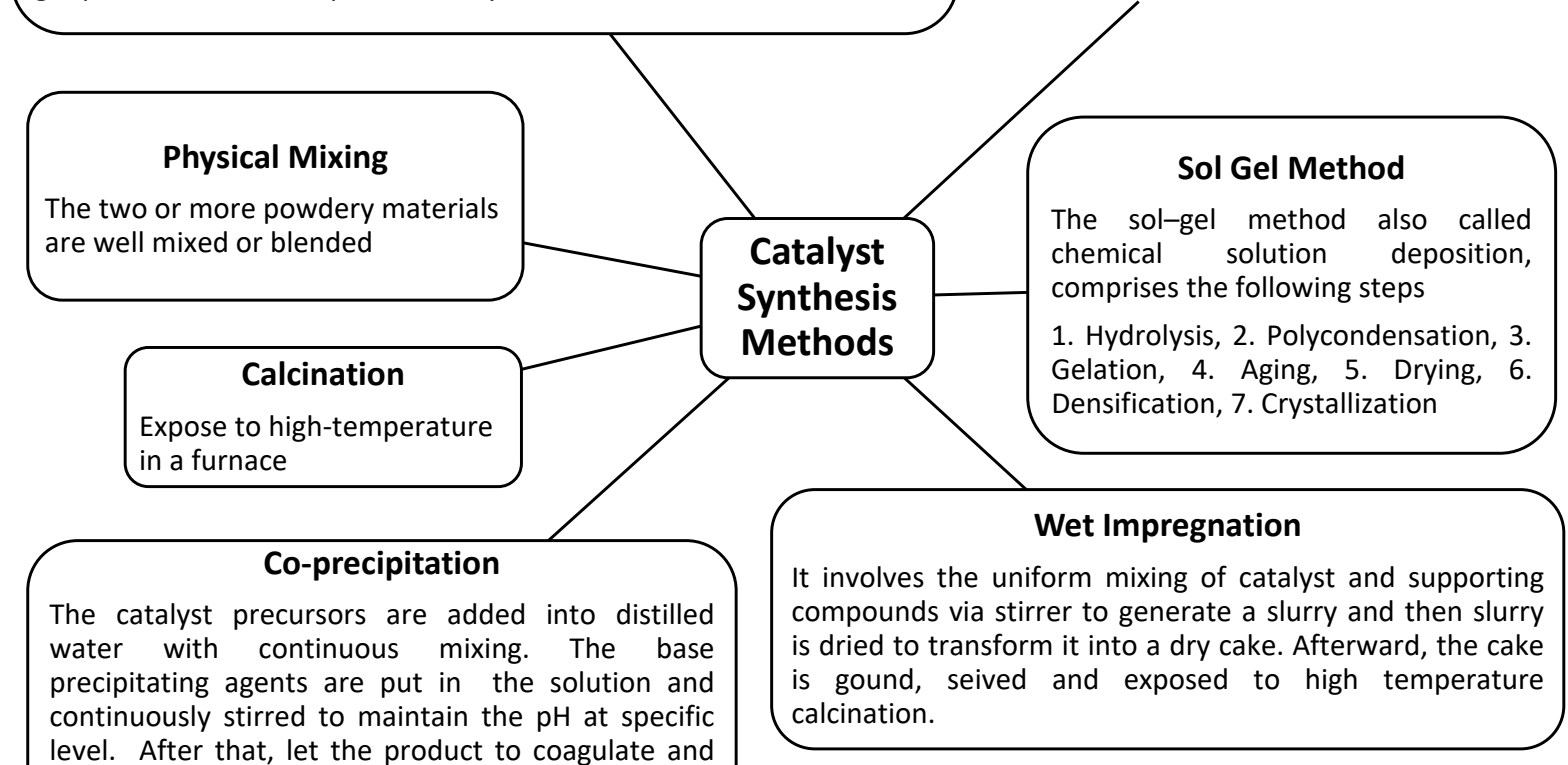

level. After that, let the product to coagulate and then dehydrate in an oven. The dried product is

exposed to calcination at a desired temperature.

Figure 3. Catalyst synthesis methods for biodiesel production using agri-waste [27-30].

\section{Evolution and Development of Agricultural Wastes-Derived Catalyst}

Owing to environmental concerns and waste management policies, several investigators have started to make efforts to transform different types of agricultural waste into green catalysts to attain cost-effective production processes and other ecological benefits. The various important factors, such as types of agricultural waste, catalyst preparation techniques, particle size, morphology, active site density, catalyst basicity, and reusability, have been considered as key research points to attain the benefits of agricultural wastederived catalysts. Moreover, reaction constraints, such as alcohol/oil molar ratio, catalyst percentage, temperature, and reaction time are required for optimization to get a maximum biodiesel yield.

For instance, waste tucuma peels, heat-treated at $800{ }^{\circ} \mathrm{C}$ for $4 \mathrm{~h}$, were applied as an effective solid catalyst in transforming soybean oil into biodiesel, displaying $97.3 \%$ yield, under specific reaction conditions [31]. Similarly, in two different places, banana peels (Musa acuminata) and wild banana peels (Musa balbisiana Colla) after open-air burning and calcination $\left(700{ }^{\circ} \mathrm{C}\right.$ for $4 \mathrm{~h}$ ), respectively, were utilized as solid catalysts for biodiesel production with yields greater than $98 \%$ in both cases [32,33]. In another study, banana peduncle upon calcination at $700{ }^{\circ} \mathrm{C}$ for $4 \mathrm{~h}$ (ramping rate: $5{ }^{\circ} \mathrm{C} / \mathrm{min}$ ) demonstrated excellent catalytic effectiveness with more than $98 \%$ biodiesel conversion [34] The discussed cases indicate that agricultural waste, after calcination, or open-air burning in some cases, showed good catalytic properties for getting biodiesel from different sources of oil.

In another investigation, the waste plant Sesamum indicum (burnt and further heattreated at $550^{\circ} \mathrm{C}$ for $2 \mathrm{~h}$ ) demonstrated an excellent catalytic performance in transformation of sunflower oil into biodiesel with a biodiesel yield of $97.9 \%$ [35]. In another study, waste 
peanut husk calcined at the temperature of $900{ }^{\circ} \mathrm{C}$ for $2 \mathrm{~h}$ and further modified with $\mathrm{Li}_{2} \mathrm{CO}_{3}$ was effectively employed as a solid catalyst for transforming soybean oil into biodiesel [36]. Even pineapple leaf ash has been used for heterogeneous catalyst development after simple calcination and was employed for converting soybean oil into biodiesel, achieving a $98 \%$ yield [37]. In another report, Tectona grandis leaves were calcined at $700{ }^{\circ} \mathrm{C}$ to synthesize a solid catalyst and this was applied in the transformation of waste cooking oil into biodiesel with a $100 \%$ yield [38]. The major ingredients found in leaf ash are oxides of calcium, potassium, and magnesium, which are responsible for the catalytic activity. Moreover, seed ashes have also been applied as a catalyst for transesterification reactions. In other research, Acai seed ash was heat-treated at the temperature of $800{ }^{\circ} \mathrm{C}$ for $4 \mathrm{~h}$ to transform it into a catalyst carrying the main elements of metal oxides and carbonates. The synthesized catalyst was employed in soybean oil based biodiesel generation. The highest biodiesel yield of $98.5 \%$ was achieved after 100 min maintaining M/O:18:1, temperature: $60{ }^{\circ} \mathrm{C}$, and a catalyst amount of $12 \mathrm{wt} . \%$ [39]. Again, the oxides and carbonates of different metals play important roles in providing active sites for reaction. Therefore, it can be deduced that high temperature heat treatment, in most cases, is sufficient to convert agricultural waste into catalytic products. Similarly, different types of agricultural waste shells, plants, and leaves upon burning and after application of some modification methods, such as calcination, coprecipitation, and bifunctional modification, have been successfully converted into efficient heterogeneous catalysts to produce biodiesel from different oil sources, as presented in Table 1. In addition, ecofriendly methods must be chosen for catalyst synthesis, keeping in mind the sustainability issues when large-scale production is needed. However, most of these catalysts have been evaluated in laboratory scale experiments. Pilot plant studies and their application in large-scale biodiesel production should also be considered to justify their commercial suitability.

\subsection{Elemental Composition and Catalytic Activity of Agricultural Waste Ashes}

As discussed earlier, different types of agricultural waste, upon treatment, such as calcination, burning, etc., are found to be efficient and effective heterogeneous catalysts in transforming a variety of oil sources into biodiesel. The elemental compositions of some of the agricultural waste ashes in their calcined forms are provided in Table 2. This indicates that most of the agri-waste ashes, such as tacuma peels, orange peels, walnut shells, and Musa balbisiana peels contain potassium and calcium as major components, which demonstrate catalytic activity in the trans-esterification reaction, either in oxide or carbonate forms. It has been reported that mixed metal oxides displayed better catalytic activity in transesterification reactions in comparison with pure metal oxides [69]. The presence of numerous materials as catalytic components in the transesterification reaction demonstrate a synergistic effect that increases the overall catalytic performance. For instance, the presence of $\mathrm{K}_{2} \mathrm{O}$ as a prime component in Mangifera indica peel ash, which is predominantly accountable for the basic strength of catalysts. Moreover, the existence of $\mathrm{CaO}$ and $\mathrm{MgO}$ in Mangifera peel ash could additionally increase the catalytic performance in reactions while other amphoteric metal oxides may assist both acid-catalyzed transesterification of oil and esterification of FFAs of vegetable oil to biodiesel [70]. In addition, the variation in the elemental composition of different waste ashes may vary the catalytic activity in terms of biodiesel yield. Therefore, such waste resources, which are otherwise an ecological burden, can be easily converted into valuable materials, such as catalysts that facilitate renewable energy production outcomes. Here, in this review, elemental composition analysis of heterogeneous catalysts made from various agricultural waste materials has been analyzed, in particular, for converting oil into biodiesel. The application of these waste ashes as catalysts is not limited to biodiesel generation. The effectiveness of these catalysts may also be tested for other applications, such as wastewater treatment and chemical transformations. 
Table 1. Agri-waste-derived catalysts for biodiesel generation.

\begin{tabular}{|c|c|c|c|c|c|c|}
\hline Agri-Waste & Catalyst Preparation & Catalyst & Oil Used & $\begin{array}{l}\text { Reaction Parameters } \\
\text { (A/O, Catalyst wt.\%, Time, } \\
\text { Temperature) }\end{array}$ & Yield & References \\
\hline $\begin{array}{l}\text { Waste tucuma peels } \\
\text { (Astrocaryum aculeatum } \\
\text { Meyer) }\end{array}$ & Calcination for $4 \mathrm{~h}$ at $800^{\circ} \mathrm{C}$ & $\begin{array}{l}\text { Components involved (K, } \mathrm{P}, \mathrm{Ca} \text {, } \\
\mathrm{Mg})\end{array}$ & Soybean oil & $15,1,240,80$ & 97.3 & [31] \\
\hline Banana peels (Musa acuminata) & $\begin{array}{l}\text { Completely burned in air to produce } \\
\text { ash. }\end{array}$ & $\mathrm{K}_{2} \mathrm{O}$ & Soybean oil & $6,0.7,240,25$ & $\mathrm{Y}=98.95$ & [33] \\
\hline Pomelo peels & $\begin{array}{l}\text { Calcined for } 2 \mathrm{~h} \text { at } 600^{\circ} \mathrm{C} \text { in nitrogen } \\
\text { environment, the specific amount of } \\
\text { pomelo peel ash was mixed with } \mathrm{KOH} \\
\text { solution for } 2 \mathrm{~h} \text { and filtered and then } \\
\text { washed with demineralized water } \\
\text { before final drying. After that, the ash } \\
\text { powder was mixed with the } \mathrm{K}_{2} \mathrm{CO}_{3} \\
\text { impregnating solution to synthesize } \\
\text { catalyst. }\end{array}$ & $\mathrm{K}_{2} \mathrm{O}$ and $\mathrm{K}_{2} \mathrm{CO}_{3}$ & Palm oil & $8,6,150,65$ & $Y>98$ & [40] \\
\hline $\begin{array}{l}\text { Wild banana peels (Musa } \\
\text { balbisiana Colla) }\end{array}$ & Calcination for $4 \mathrm{~h}$ at $700^{\circ} \mathrm{C}$. & High percentage of potassium & WCO & $6,2,180,60$ & $\mathrm{Y}=100$ & [32] \\
\hline $\begin{array}{l}\text { Pineapple (Ananás comosus) } \\
\text { leaves ash }\end{array}$ & $\begin{array}{l}\text { Calcination for } 2 \mathrm{~h} \text { at } 600^{\circ} \mathrm{C} \text { and for } 1 \mathrm{~h} \\
\text { at } 900^{\circ} \mathrm{C} \text {. }\end{array}$ & $\begin{array}{l}\text { Catalytic performance may be } \\
\text { owing to the reasonable } \\
\text { proportion of } \mathrm{K}, \mathrm{Ca} \text { and } \mathrm{Mg}\end{array}$ & Soybean oil & $40,4,30,60$ & $\mathrm{Y}=98$ & [37] \\
\hline Waste Brassica nigra plant & Burnt and heat-treated at $550^{\circ} \mathrm{C}$ for $2 \mathrm{~h}$. & $\mathrm{K}_{2} \mathrm{O}, \mathrm{K}_{2} \mathrm{CO}_{3}$ and $\mathrm{KCl}$ & Soybean oil & $12,7,25,65$ & $\mathrm{Y}=98.79$ & [41] \\
\hline Waste Sesamum indicum plant & Burnt and calcined at $550^{\circ} \mathrm{C}$ for $2 \mathrm{~h}$. & Due to $\mathrm{K}$ and $\mathrm{Ca}$ components & Sunflower oil & $12,7,40,65$ & $Y=97.9$ & [35] \\
\hline Banana peduncle & Calcination for $4 \mathrm{~h}$ at $700^{\circ} \mathrm{C}$. & $\begin{array}{l}\text { The presence of metallic } \\
\text { components such as } \mathrm{K}, \mathrm{Ca} \text {, and } \\
\mathrm{Mg}\end{array}$ & Ceiba pentandra oil & $9.2,1.978,60,70$ & $C=98.69 \pm 0.18 \%$ & [34] \\
\hline $\begin{array}{l}\text { Musa paradisiacal (plantain) } \\
\text { peels }\end{array}$ & Calcined at $500^{\circ} \mathrm{C}$ for $3.5 \mathrm{~h}$. & $\begin{array}{l}\text { The catalytic activity may be } \\
\text { owing to high proportion of } \\
\text { potassium }\end{array}$ & Thevetia peruviana oil & $0.3(v / v), 3.0 \%(w / v), 90,60$ & $Y=94.87$ & [42] \\
\hline Acai seed ash & Calcination for $4 \mathrm{~h}$ at $800^{\circ} \mathrm{C}$. & $\begin{array}{l}\text { The major components are } \\
\text { metal oxides and carbonates }\end{array}$ & Soybean oil & $18,12,60,100$ & $\mathrm{Y}=98.5$ & [39] \\
\hline Walnut shell ash & Burnt and calcined at $800^{\circ} \mathrm{C}$. & $\mathrm{Ca}, \mathrm{K}, \mathrm{Mg}, \mathrm{Si}$ & Sunflower oil & $12,5,10,60$ & $\mathrm{Y}=98$ & [43] \\
\hline $\begin{array}{l}\text { Waste cupuaçu (Theobroma } \\
\text { grandiflorum) seeds }\end{array}$ & Calcined for $4 \mathrm{~h}$ at $800^{\circ} \mathrm{C}$. & $\begin{array}{l}\text { The catalytic activity mainly } \\
\text { attributed to potassium }\end{array}$ & Soybean oil & $10,10,480,80$ & $Y=98.36$ & [44] \\
\hline
\end{tabular}


Table 1. Cont.

\begin{tabular}{|c|c|c|c|c|c|c|}
\hline Agri-Waste & Catalyst Preparation & Catalyst & Oil Used & $\begin{array}{l}\text { Reaction Parameters } \\
\text { (A/O, Catalyst wt.\%, Time, } \\
\text { Temperature) }\end{array}$ & Yield & References \\
\hline Tectona grandis leaves & Calcination at $700^{\circ} \mathrm{C}$ for $4 \mathrm{~h}$. & $\begin{array}{l}\text { Heterogeneous base catalyst } \\
\text { having } \mathrm{CaO}, \mathrm{K}_{2} \mathrm{O}, \mathrm{MgO}, \mathrm{K}_{2} \mathrm{CO}_{3}, \\
\mathrm{SiO}_{2}\end{array}$ & Waste cooking oil & $6,2.5,180,25$ & $Y=100$ & [38] \\
\hline Waste rice-straw & $\begin{array}{l}\text { First, heat treated for } 5 \mathrm{~h} \text { at } 700{ }^{\circ} \mathrm{C} \text {. The } \\
\text { specific calcined amount was mixed } \\
\text { with } 1 \mathrm{M} \mathrm{NaOH} \text { solution and performed } \\
\text { boiling for } 2 \mathrm{~h} \text { in a flask and dried. After } \\
\text { drying, again calcined at various } \\
\text { temperatures between } 350{ }^{\circ} \mathrm{C} \text { and } \\
500^{\circ} \mathrm{C} \text {. }\end{array}$ & Sodium silicate $\left(\mathrm{Na}_{2} \mathrm{SiO}_{3}\right)$ & Waste cooking oil & $15,3.5,150,65$ & $Y=93.7$ & [45] \\
\hline Waste rubber seed shell & Calcined at $800^{\circ} \mathrm{C}$ & $\begin{array}{l}\mathrm{CaO} \text { generated from rubber } \\
\text { seed shells, upon calcination } \\
\text { indicated basic catalytic } \\
\text { properties }\end{array}$ & Rubber seed oil & $0.2 v / v, 2.5 \mathrm{~g}, 60,60$ & $Y=83.06 \pm 0.013 \%$ & [46] \\
\hline $\begin{array}{l}\text { Musa acuminata banana trunk } \\
\text { ash }\end{array}$ & $\begin{array}{l}\text { The trunk was burnt and ground to a } \\
\text { fine ash catalyst. }\end{array}$ & $\begin{array}{l}\text { Oxides of potassium, calcium } \\
\text { and magnesium deliver strong } \\
\text { basic sites on catalytic surface }\end{array}$ & Soybean oil & $6,0.5 \mathrm{~g}, /, 25$ & $Y=98.39$ & [47] \\
\hline Wheat bran ash & $\begin{array}{l}\text { Calcined at } 700^{\circ} \mathrm{C} \text { for } 4 \mathrm{~h} \text { and } \mathrm{CaO} \text { was } \\
\text { obtained from the water scale taken from } \\
\text { the distillation assembly. After washing } \\
\text { with demineralized water, precipitated } \\
\text { were dried at } 120^{\circ} \mathrm{C} \text { for } 24 \mathrm{~h} \text {. Next, the } \\
\text { temperature was elevated to } 900^{\circ} \mathrm{C} \text { and } \\
\text { the precipitates were calcined for } 2 \mathrm{~h} \text { at } \\
900^{\circ} \mathrm{C} \text {. The blend of precipitate } \\
(40 \mathrm{wt} . \%) \text { and wheat bran }(60 \mathrm{wt} . \%) \text { ash } \\
\text { was synthesized as catalyst. }\end{array}$ & Wheat ran ash/CaO & Waste cooking oil & $12,11.66,114.21,54.6$ & $Y=93.6$ & [49] \\
\hline
\end{tabular}


Table 1. Cont.

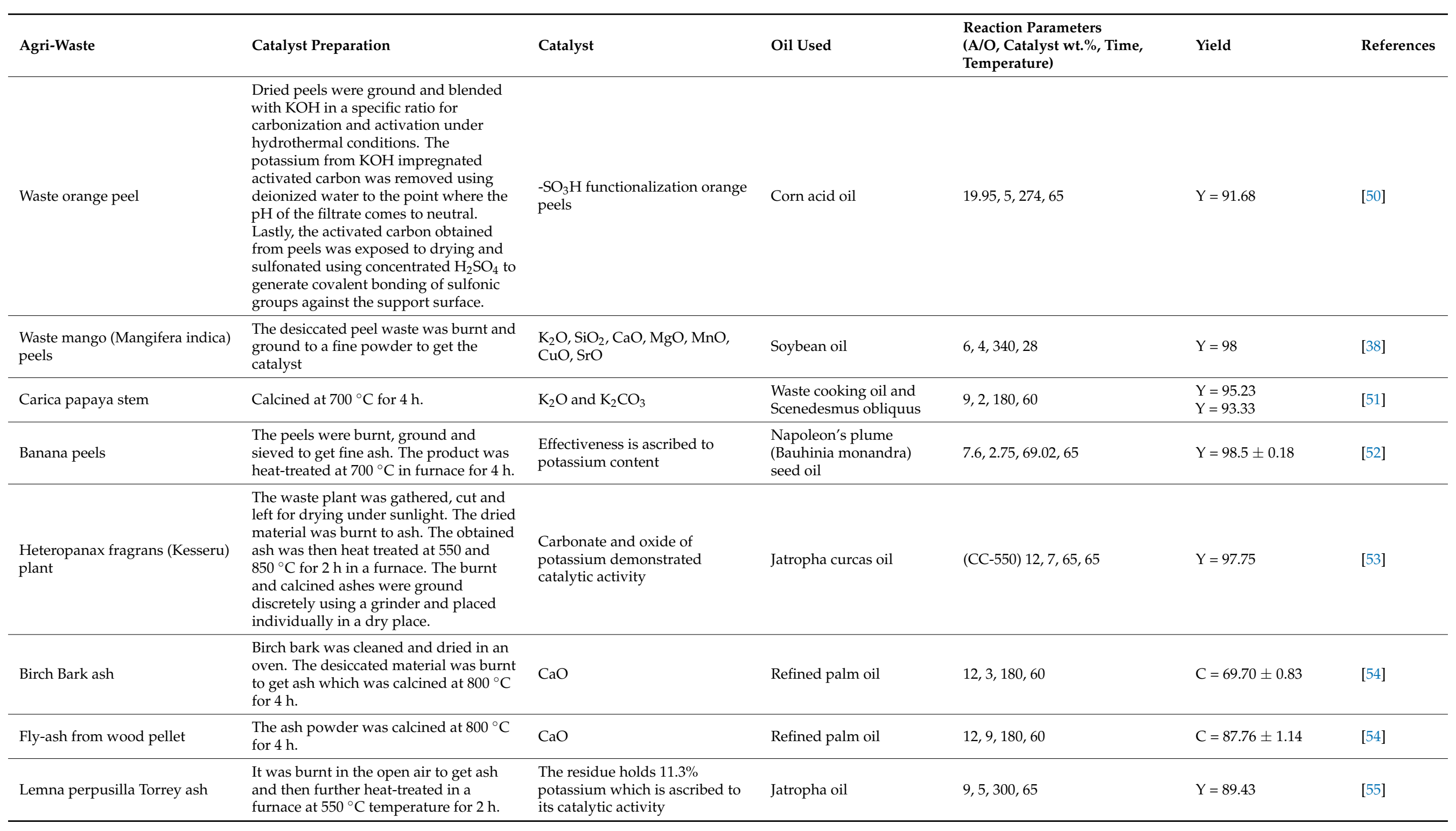


Table 1. Cont.

\begin{tabular}{|c|c|c|c|c|c|c|}
\hline Agri-Waste & Catalyst Preparation & Catalyst & Oil Used & $\begin{array}{l}\text { Reaction Parameters } \\
\text { (A/O, Catalyst wt.\%, Time, } \\
\text { Temperature) }\end{array}$ & Yield & References \\
\hline Orange peel ash & $\begin{array}{l}\text { The peels were washed, cut and dried } \\
\text { for } 3 \text { days. The dried material was burnt } \\
\text { for } 30 \text { min and milled to produce ash. }\end{array}$ & $\begin{array}{l}\text { The availability of basic sites } \\
\text { such as } \mathrm{K} \text { and } \mathrm{Ca}\end{array}$ & Soybean oil & $6,7,420,25$ & $C=98$ & [56] \\
\hline $\begin{array}{l}\text { Raw sugar beet agro-industrial } \\
\text { waste }\end{array}$ & $\begin{array}{l}\text { Raw sugar beet industrial waste was } \\
\text { dried, milled and calcined for } 2 \mathrm{~h} \text { at } \\
\text { various temperatures varying from } \\
600{ }^{\circ} \mathrm{C} \text { to } 1000^{\circ} \mathrm{C} \text {. }\end{array}$ & $\mathrm{CaO}$ & Sunflower oil & $4.5,1,60,75$ & $C=93$ & [57] \\
\hline Murumuru kernel shell biochar & $\begin{array}{l}\text { The crushed shell of specific particle size } \\
\text { was charred in a tubular furnace for } 1 \mathrm{~h} \\
\text { at } 600{ }^{\circ} \mathrm{C} \text {. After that the product was } \\
\text { further marinated to reduce the particle } \\
\text { size. After that the sulfonation } \\
\text { procedure was carried out for biochar } \\
\text { functionalization. }\end{array}$ & $\mathrm{MKSB}-\mathrm{SO}_{3} \mathrm{H}$ & Jupati oil & $30,6,240,135$ & $Y=91.8$ & [58] \\
\hline Waste ginger straw & $\begin{array}{l}\text { The ginger straw was crushed and } \\
\text { sieved. After that the obtained powder } \\
\text { was charred under } \mathrm{N}_{2} \text { atmosphere at the } \\
\text { specified temperature and for the } \\
\text { specified time. Later, the sulfonation } \\
\text { was carried out. The resulting ppt was } \\
\text { then cleaned with hot distilled water } \\
\text { and dried. }\end{array}$ & $\begin{array}{l}\text { The catalyst synthesized via } \\
\text { carbonization holding an } \\
\text { amorphous carbon structure } \\
\text { with a sulfonic group density of } \\
1.05 \mathrm{mmol} / \mathrm{g}\end{array}$ & Oleic acid & $9,7,210,64$ & $Y=93.2$ & [59] \\
\hline Waste Musa paradisiaca trunk & $\begin{array}{l}\text { After harvesting, M. paradisiaca trunk } \\
\text { was pieced and dried in sunlight and } \\
\text { then burnt to get ash. The ash is further } \\
\text { calcined for } 2 \mathrm{~h} \text { at } 5500^{\circ} \mathrm{C} \text { and crushed to } \\
\text { a fine powder. }\end{array}$ & $\begin{array}{l}\text { Potassium as } \mathrm{K}_{2} \mathrm{CO}_{3}, \mathrm{KCl} \text { and } \\
\mathrm{K}_{2} \mathrm{O} \text {, }\end{array}$ & Jatropha oil & $9,5,9,65$ & $Y=97.65$ & [53] \\
\hline $\begin{array}{l}\text { Tamarindus Indica fruit shell } \\
\text { ash }\end{array}$ & $\begin{array}{l}\text { The crushed catalyst precursor was } \\
\text { heat-treated in furnace at } 800^{\circ} \mathrm{C} \text { for } 3 \mathrm{~h} \\
\text { with an increment of } 5^{\circ} \mathrm{C} / \mathrm{min} \text { to obtain } \\
\text { shell ash. }\end{array}$ & $\mathrm{CaO}$ & P. curatellifolia seeds oil & $9,5,120,60$ & $Y=96.2$ & [60] \\
\hline Waste peanut husk & $\begin{array}{l}\text { Calcined at } 900.5^{\circ} \mathrm{C} \text { for } 2 \mathrm{~h} \text {, a highly } \\
\text { active solid catalyst may be found by } \\
\text { mixing and well- ground waste peanut } \\
\text { husks with } \mathrm{Li}_{2} \mathrm{CO}_{3} \text { calcined in air for } \\
4 \mathrm{~h} \text {. }\end{array}$ & $\begin{array}{l}\mathrm{Li}_{2} \mathrm{CO}_{3} \text {-modified waste peanut } \\
\text { husks }\end{array}$ & Soybean oil & $12,5,240,65$ & $\mathrm{Y}=98.4$ & [36] \\
\hline
\end{tabular}


Table 1. Cont.

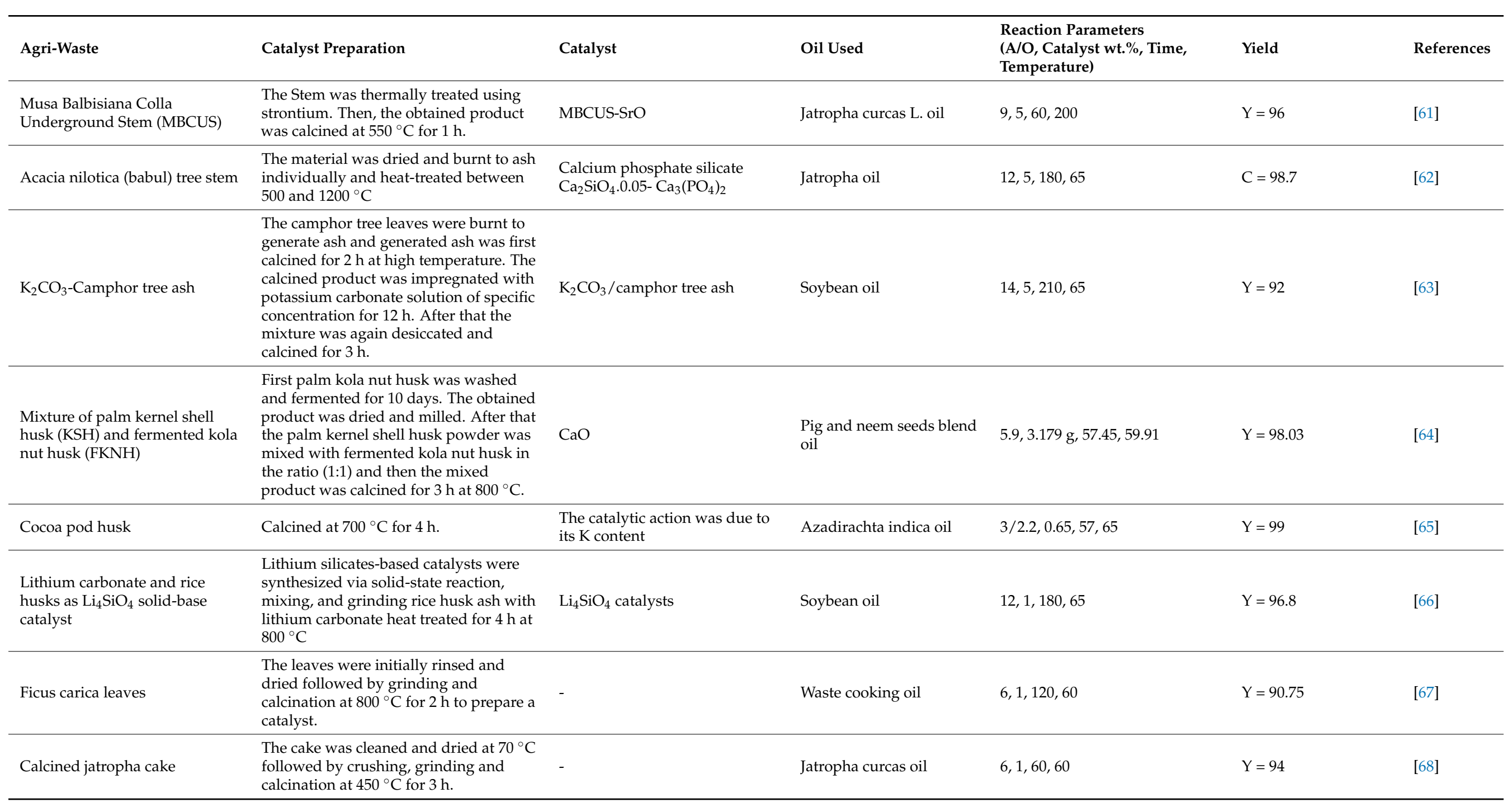


Table 2. Elemental composition of differently sourced agricultural waste.

\begin{tabular}{|c|c|c|c|c|c|c|}
\hline \multirow{2}{*}{ Calcined Agricultural Waste Ash } & \multicolumn{6}{|c|}{ Major Elemental Composition (\%) } \\
\hline & $\mathrm{Ca}$ & $\mathbf{K}$ & $\mathbf{P}$ & $\mathrm{Mg}$ & $\mathrm{Na}$ & References \\
\hline Waste tucuma peels & 12.28 & 63.81 & 12.67 & 6.69 & traces & {$[31]$} \\
\hline Banana peels & 0.03 & 99.73 & - & 0.03 & 0.19 & [52] \\
\hline Brassica nigra plant & 26.04 & 56.13 & - & 2.86 & 0.94 & [41] \\
\hline Sesamum indicum plant & 33.80 & 29.64 & - & 9.68 & 1.42 & [35] \\
\hline Orange peel ash upon burning (in oxide form) & 25.67 & 51.64 & 2.95 & 4.76 & 1.81 & [56] \\
\hline Mangifera indica peel (in oxide form) & 4.20 & 59.14 & 3.92 & 8.08 & 1.58 & [70] \\
\hline Tectona grandis leaves & 30.28 & 53.25 & - & 4.77 & 1.67 & [38] \\
\hline Cocoa pod husk-plantain peel blend & 2.3 & 50.95 & 1.38 & 2.49 & - & [48] \\
\hline Walnut shell ash & 17.67 & 23.55 & - & traces & - & [43] \\
\hline Musa balbisiana peels & 36.08 & 41.37 & - & 12.02 & 10.41 & {$[32]$} \\
\hline Brassica nigra & 26.04 & 56.13 & - & 2.86 & 0.94 & [41] \\
\hline Lemna perpusilla & - & 11.32 & - & - & 0.53 & {$[55]$} \\
\hline Carica papaya stem & 21.08 & 56.71 & - & 4.41 & 14.78 & {$[51]$} \\
\hline Banana peduncle & 5.27 & 52.04 & - & 5.71 & - & {$[34]$} \\
\hline
\end{tabular}

\subsection{Parametric Optimization Study}

In addition to the effectiveness of the catalyst in reaction, the biodiesel conversion/yield is significantly controlled by different reaction parameters, such as alcohol/oil (mole basis), catalyst weight \%, reaction temperature and time, and mixing intensity. Owing to the reversible nature of the transesterification reaction, surplus methanol from its stoichiometric amount is desired to move the equilibrium forward and to enhance the biodiesel yield. This would assist in the generation of $\mathrm{OCH}_{3}$ - on the surface of the catalyst and, therefore, positively alter the biodiesel yield [71]. However, excessive methanol above the optimum value will not affect conversion and rather adds an extra cost for its recovery. It could be possible reason that too much methanol in the reaction mixture may dissolve in already generated glycerol, which obstructs the methanol reaction to the catalyst and oil [72]. Similarly, the quantity of catalyst present in the reaction mixture affects the biodiesel yield. The biodiesel yield increases upon addition of more catalyst, which indicates that a higher amount of catalyst may make more active sites available, which are directly related to conversion $[73,74]$. However, beyond the optimum quantity, the yield begins to decrease, which could be due to the rise in the viscosity of the mixture and probably some amount of catalyst might not be suitably exploited due to mass transfer resistance, therefore, decreasing the conversion [74]. Moreover, the reaction temperature also strongly affects the biodiesel yield. An optimal temperature is mandatory overcoming the resistance of diffusion generated among multiple phases of a heterogeneously catalyzed process to attain maximum conversion. High temperature generally favors collusion between molecules, thereby improving miscibility and mass transfer [75]. However, if the temperature is not maintained at an optimum value, the yield may decrease owing to methanol vaporization. The optimized reaction parameters with improved biodiesel yield described in the literature, using agricultural waste-based heterogeneous catalysts, are demonstrated in Table 1. It can be assumed that in addition to the catalytic activity and performance, it is necessary to tradeoff between the reaction parameters to get highest yield of biodiesel.

\subsection{Agri-Waste Derived Catalyst Reusability}

The catalysts derived from agricultural waste, such as peels of different fruits, stems, leaves, and husks, displayed excellent catalytic reusability in transesterification, which is an important parameter concerning the sustainability of catalysts. Various investigators have explored the reusability of agri-waste-derived catalysts for multiple runs. For example, Nath et al. [41] noted the reusability of waste Brassica nigra plant-derived catalyst for three successive runs with a biodiesel yield of $96 \%$, indicating a minor loss in catalytic activity. 
In another similar investigation, catalyst derived from the banana trunk showed a yield reduction to $91 \%$ in the third cycle from $96 \%$ in the first run [76]. Similarly, a $20 \%$ yield reduction in third consecutive run was described by Sarma et al. [77]. Mendonça et al. [31] also described catalyst reusability gained from waste tucumã peels, up to 5 runs, with a $17.3 \%$ reduction in catalytic activity. The reason for this drop in catalytic activity could be leaching or a loss of active components during successive transesterification reactions. The reasonable reusability of agri-waste-based catalysts to generate biodiesel indicates the commercial viability of agricultural waste-derived catalysts for the sustainable production of biodiesel.

\section{Biodiesel Production via Heterogeneously Catalyzed Technology}

Presently, commercial-scale biodiesel generation mostly comprises homogeneous catalyzed process technology. Nevertheless, there are several leading technology companies that are making efforts to develop and operate heterogeneous catalyzed process technologies. For example, a biodiesel refinery based on a novel heterogeneous catalyst was established by Benefuel, Inc., in Seymour, U.S. [78]. A biodiesel industry with 0.16 million tons of capacity per year is located in Sete, France, and is operated using heterogeneous catalyzed process technology. Correspondingly, $8000 \mathrm{MT} /$ annum of biodiesel was industrialized in Malaysia by Biofuel, Ltd., in cooperation with Incbio [79]. It seems that commercial scale biodiesel production using heterogeneous catalysts has been established. Most often, catalysts are synthesized from technical grade reagents to achieve a high performance and reliable results rather than being manufactured from waste resources. There could be possible drawbacks associated with waste-based catalyst synthesis, including sustainability and availability of same category of waste resources, their varied compositions and purity levels, selectivity, length of time, and cost evaluation of processing steps involved in waste-based catalyst synthesis. These factors may explicitly or implicitly link to the performance and reliability of a catalyst and, therefore, biodiesel yield and its quality parameters may be negatively influenced. Therefore, catalysts synthesized from synthetic chemicals/technical grade reagents are considered more reliable with respect to their design and performance. There are numerous researchers presently involved in evaluating the effectiveness of agricultural waste-based catalysts, but there still needs to be an extensive evaluation of these catalysts for large-scale production and their commercial utilization. Owing to the profits associated with heterogeneous-based catalyst systems, it has become essential to encourage its marketable development and applicability. It would be an excellent opportunity if heterogeneous catalysts were produced from waste materials, such as agricultural waste, which is amply generated each year across the world.

\section{Conclusions}

Although agricultural waste is considered as waste, it possesses vast potential to be transformed into valuable materials, such as catalysts, which facilitate the biodiesel production process in a feasible and sustainable way. If this waste is left unused, it would create disposal issues and sanitation problems owing to its inappropriate disposal. With a growing population, the intensity of agricultural waste generation is also continuously increasing because of growing consumption and utilization of agricultural products. This work focused on reviewing the transformation of different types of agricultural waste into valuable catalysts that have been efficiently and effectively utilized in the biodiesel production process. Waste-derived catalyst synthesis for biodiesel production would ultimately lessen biodiesel production costs and its pump price. Agricultural wastederived catalysts can be manufactured using various methods, such as calcination, physical mixing, wet impregnation, sol-gel method, to improve the effectiveness of catalysts. These wastes-based heterogeneous catalysts are easy to fabricate, highly active, and reusable, along with providing options to get rid of homogeneous catalyzed process technologies and their associated drawbacks, which are presently commercially active. There is a need for extensive evaluation of these catalysts for large-scale production and their commercial 
utilization. In addition, a summary of agricultural waste-derived catalysts that are being utilized in biodiesel production processes might encourage researchers to explore various unexplored waste materials that can be potentially converted into valuable materials. Here, in this study, elemental composition analyses of heterogeneous catalysts made from various agricultural waste materials has been reviewed, particularly for transforming oil into biodiesel. The effectiveness of these catalysts may also be tested for other applications, such as wastewater treatment and chemical transformations.

Author Contributions: Conceptualization, H.M.K. and M.M.A.; writing-original draft preparation, H.M.K. and M.M.A.; writing-review and editing, T.I., S.Y., M.E.M.S., C.H.A., A.H., M.M.R. and M.A.J. All authors have read and agreed to the published version of the manuscript.

Funding: This research received no external funding.

Acknowledgments: The authors acknowledge and appreciate the support provided by King Faisal University (KFU), Saudi Arabia, for providing necessary support and assistance for conducting this research.

Conflicts of Interest: The authors declare no conflict of interest.

\section{References}

1. Shan, R.; Chen, G.; Yan, B.; Shi, J.; Liu, C. Porous CaO-based catalyst derived from PSS-induced mineralization for biodiesel production enhancement. Energy Convers. Manag. 2015, 106, 405-413. [CrossRef]

2. Mujtaba, M.; Kalam, M.; Masjuki, H.; Razzaq, L.; Khan, H.M.; Soudagar, M.E.M.; Gul, M.; Ahmed, W.; Raju, V.D.; Kumar, R.; et al. Development of empirical correlations for density and viscosity estimation of ternary biodiesel blends. Renew. Energy 2021, 179, 1447-1457. [CrossRef]

3. Soudagar, M.; Khan, H.; Khan, T.; Razzaq, L.; Asif, T.; Mujtaba, M.; Hussain, A.; Farooq, M.; Ahmed, W.; Shahapurkar, K.; et al. Experimental analysis of engine performance and exhaust pollutant on a single-cylinder diesel engine operated using moringa oleifera biodiesel. Appl. Sci. 2021, 11, 7071. [CrossRef]

4. Mujtaba, M.; Kalam, M.; Masjuki, H.; Soudagar, M.E.M.; Khan, H.M.; Fayaz, H.; Farooq, M.; Gul, M.; Ahmed, W.; Ahmad, M.; et al. Effect of palm-sesame biodiesel fuels with alcoholic and nanoparticle additives on tribological characteristics of lubricating oil by four ball tribo-tester. Alex. Eng. J. 2021, 60, 4537-4546. [CrossRef]

5. Abdullah, S.H.Y.S.; Hanapi, N.H.M.; Azid, A.; Umar, R.; Juahir, H.; Khatoon, H.; Endut, A. A review of biomass-derived heterogeneous catalyst for a sustainable biodiesel production. Renew. Sustain. Energy Rev. 2017, 70, 1040-1051. [CrossRef]

6. Mujtaba, M.A.; Cho, H.M.; Masjuki, H.H.; Kalam, M.A.; Farooq, M.; Soudagar, M.E.M.; Gul, M.; Ahmed, W.; Afzal, A.; Bashir, S.; et al. Effect of alcoholic and nano-particles additives on tribological properties of diesel-palm-sesame-biodiesel blends. Energy Rep. 2021, 7, 1162-1171. [CrossRef]

7. Krishna, B.M.; Mallikarjuna, J.M. Properties and performance of cotton seed oil-diesel blends as a fuel for compression ignition engines. J. Renew. Sustain. Energy 2009, 1, 023106. [CrossRef]

8. Khan, H.M.; Ali, C.H.; Iqbal, T.; Yasin, S.; Sulaiman, M.; Mahmood, H.; Raashid, M.; Pasha, M.; Mu, B.-Z. Current scenario and potential of biodiesel production from waste cooking oil in Pakistan: An overview. Chin. J. Chem. Eng. 2019, 27, 2238-2250. [CrossRef]

9. Khan, H.M.; Iqbal, T.; Yasin, S.; Irfan, M.; Kazmi, M.; Fayaz, H.; Mujtaba, M.; Ali, C.H.; Kalam, M.; Soudagar, M.E.M.; et al. Production and utilization aspects of waste cooking oil based biodiesel in Pakistan. Alex. Eng. J. 2021, 60, 5831-5849. [CrossRef]

10. Su, F.; Guo, Y. Advancements in solid acid catalysts for biodiesel production. Green Chem. 2014, 16, 2934-2957. [CrossRef]

11. Mujtaba, M.; Cho, H.M.; Masjuki, H.; Kalam, M.; Ong, H.; Gul, M.; Harith, M.; Yusoff, M. Critical review on sesame seed oil and its methyl ester on cold flow and oxidation stability. Energy Rep. 2020, 6, 40-54. [CrossRef]

12. Luque, R.; Lovett, J.C.; Datta, B.; Clancy, J.; Campelo, J.M.; Romero, A.A. Biodiesel as feasible petrol fuel replacement: A multidisciplinary overview. Energy Environ. Sci. 2010, 3, 1706-1721. [CrossRef]

13. Kumar, M.; Sharma, M.P. Selection of potential oils for biodiesel production. Renew. Sustain. Energy Rev. 2016, 56, 1129-1138. [CrossRef]

14. Semwal, S.; Arora, A.K.; Badoni, R.P.; Tuli, D.K. Biodiesel production using heterogeneous catalysts. Bioresour. Technol. 2011, 102, 2151-2161. [CrossRef] [PubMed]

15. Amani, H.; Ahmad, Z.; Hameed, B. Highly active alumina-supported Cs-Zr mixed oxide catalysts for low-temperature transesterification of waste cooking oil. Appl. Catal. A Gen. 2014, 487, 16-25. [CrossRef]

16. Lee, A.F.; Bennett, J.A.; Manayil, J.C.; Wilson, K. ChemInform abstract: Heterogeneous catalysis for sustainable biodiesel production via. esterification and transesterification. Chem. Soc. Rev. 2014, 46, 7887-7916. [CrossRef]

17. Lu, Y.; Zhang, Z.; Xu, Y.; Liu, Q.; Qian, G. CaFeAl mixed oxide derived heterogeneous catalysts for transesterification of soybean oil to biodiesel. Bioresour. Technol. 2015, 190, 438-441. [CrossRef] 
18. Paterson, G.; Issariyakul, T.; Baroi, C.; Bassi, A.; Dalai, A. Ion-exchange resins as catalysts in transesterification of triolein. Catal. Today 2013, 212, 157-163. [CrossRef]

19. Food and Agriculture Organizationof the United Nations (FAO). Strategic work of FAO for Sustainable Food Andagriculture. Available online: http:/ / www.fao.org/3/a-i6488e.pdf (accessed on 1 October 2021).

20. Food and Agriculture Organization of the United Nations (FAO) \& Organization for Economic Co-operation and Development (OECD). Background Notes on Sustainable, Productive and Resilient Agrofood Systems: Value Chains, Human Capital, and the 2030 Agenda. A Report to the G20 Agriculture Deputies. Available online: https:/ / www.oecdilibrary.org/docserver/dca82200en.pdf? expires=15639591\&id=id\&accname=guest\&checksum=5BD0A7A51327DB165936B4AE57A0E5CE (accessed on 1 October 2021).

21. Adejumo, I.O.; Adebiyi, O.A. Agricultural solid wastes: Causes, effects, and effective management. In Strategies of Sustainable Solid Waste Management; IntechOpen: London, UK, 2021.

22. European Commission Investing in Sustainable Development. In The EU at the Forefront in Implementing the Addis Ababa Action Agenda European Commission; EU Publications: Brussels, Belgium, 2018.

23. United Nations. Programme Performance Report 2018. UN Environment Programme. Available online: https://wedocs.unep org/bitstream/handle/20.500.11822/27734/PPR_2018_FINAL.pdf?sequence=1\&isAllowed=y (accessed on 1 October 2021).

24. Sadh, P.K.; Duhan, S.; Duhan, J.S. Agro-industrial wastes and their utilization using solid state fermentation: A review. Bioresour. Bioprocess. 2018, 5, 1-13. [CrossRef]

25. Belewu, M.; Babalola, F. Nutrient enrichment of waste agricultural residues after solid state fermentation using Rhizopus oligosporus. J. Appl. Biosci. 2009, 13, 695-699.

26. Mussatto, S.I.; Ballesteros, L.F.; Martins, S.; Teixeira, J.A. Use of agro-industrial wastes in solid-state fermentation processes. Ind. Waste 2012, 274, 122-140. [CrossRef]

27. Awogbemi, O.; Von Kallon, D.V.; Aigbodion, V.S. Trends in the development and utilization of agricultural wastes as heterogeneous catalyst for biodiesel production. J. Energy Inst. 2021, 98, 244-258. [CrossRef]

28. Etim, A.O.; Musonge, P.; Eloka-Eboka, A.C. Effectiveness of biogenic waste-derived heterogeneous catalysts and feedstock hybridization techniques in biodiesel production. Biofuels Bioprod. Biorefin. 2020, 14, 620-649. [CrossRef]

29. Khan, H.M.; Iqbal, T.; Ali, C.H.; Javaid, A.; Cheema, I.I. Sustainable biodiesel production from waste cooking oil utilizing waste ostrich (Struthio camelus) bones derived heterogeneous catalyst. Fuel 2020, 277, 118091. [CrossRef]

30. Mansir, N.; Teo, S.; Rashid, U.; Saiman, M.I.; Tan, Y.P.; Alsultan, A.; Taufiq-Yap, Y.H. Modified waste egg shell derived bifunctional catalyst for biodiesel production from high FFA waste cooking oil. A review. Renew. Sustain. Energy Rev. 2018, 82, $3645-3655$. [CrossRef]

31. Mendonça, I.M.; Paes, O.A.; Maia, P.J.; Souza, M.P.; Almeida, R.A.; Silva, C.C.; Duvoisin, S., Jr.; de Freitas, F.A. New heterogeneous catalyst for biodiesel production from waste tucumã peels (Astrocaryum aculeatum Meyer): Parameters optimization study. Renew. Energy 2019, 130, 103-110. [CrossRef]

32. Gohain, M.; Devi, A.; Deka, D. Musa balbisiana Colla peel as highly effective renewable heterogeneous base catalyst for biodiesel production. Ind. Crop. Prod. 2017, 109, 8-18. [CrossRef]

33. Pathak, G.; Das, D.; Rajkumari, K.; Rokhum, S.L. Exploiting waste: Towards a sustainable production of biodiesel using Musa acuminata peel ash as a heterogeneous catalyst. Green Chem. 2018, 20, 2365-2373. [CrossRef]

34. Balajii, M.; Niju, S. Banana peduncle-a green and renewable heterogeneous base catalyst for biodiesel production from Ceiba pentandra oil. Renew. Energy 2020, 146, 2255-2269. [CrossRef]

35. Nath, B.; Kalita, P.; Das, B.; Basumatary, S. Highly efficient renewable heterogeneous base catalyst derived from waste Sesamum indicum plant for synthesis of biodiesel. Renew. Energy 2020, 151, 295-310. [CrossRef]

36. Dai, Y.-M.; Chen, K.-T.; Wang, Y.-J.; Chen, C.-C. Application of peanut husk ash as a low-cost solid catalyst for biodiesel production. Int. J. Chem. Eng. Appl. 2014, 5, 276-280. [CrossRef]

37. Barros, S.D.S.; Junior, W.A.P.; Sá, I.S.; Takeno, M.L.; Nobre, F.X.; Pinheiro, W.; Manzato, L.; Iglauer, S.; de Freitas, F.A. Pineapple (Ananás comosus) leaves ash as a solid base catalyst for biodiesel synthesis. Bioresour. Technol. 2020, 312, 123569. [CrossRef] [PubMed]

38. Gohain, M.; Laskar, K.; Phukon, H.; Bora, U.; Kalita, D.; Deka, D. Towards sustainable biodiesel and chemical production: Multifunctional use of heterogeneous catalyst from littered Tectona grandis leaves. Waste Manag. 2020, 102, 212-221. [CrossRef] [PubMed]

39. Mares, E.K.L.; Gonçalves, M.A.; da Luz, P.T.S.; Filho, G.N.D.R.; Zamian, J.R.; da Conceição, L.R.V. Acai seed ash as a novel basic heterogeneous catalyst for biodiesel synthesis: Optimization of the biodiesel production process. Fuel 2021, 299 , 120887. [CrossRef]

40. Zhao, C.; Lv, P.; Yang, L.; Xing, S.; Luo, W.; Wang, Z. Biodiesel synthesis over biochar-based catalyst from biomass waste pomelo peel. Energy Convers. Manag. 2018, 160, 477-485. [CrossRef]

41. Nath, B.; Das, B.; Kalita, P.; Basumatary, S. Waste to value addition: Utilization of waste Brassica nigra plant derived novel green heterogeneous base catalyst for effective synthesis of biodiesel. J. Clean. Prod. 2019, 239, 118112. [CrossRef]

42. Betiku, E.; Ajala, S.O. Modeling and optimization of Thevetia peruviana (yellow oleander) oil biodiesel synthesis via Musa paradisiacal (plantain) peels as heterogeneous base catalyst: A case of artificial neural network vs. response surface methodology. Ind. Crop. Prod. 2014, 53, 314-322. [CrossRef] 
43. Miladinović, M.R.; Zdujić, M.V.; Veljović, D.N.; Krstić, J.B.; Banković-Ilić, I.B.; Veljković, V.B.; Stamenković, O.S. Valorization of walnut shell ash as a catalyst for biodiesel production. Renew. Energy 2020, 147, 1033-1043. [CrossRef]

44. Mendonça, I.M.; Machado, F.L.; Silva, C.C.; Junior, S.D.; Takeno, M.; Maia, P.J.D.S.; Manzato, L.; de Freitas, F.A. Application of calcined waste cupuaçu (Theobroma grandiflorum) seeds as a low-cost solid catalyst in soybean oil ethanolysis: Statistical optimization. Energy Convers. Manag. 2019, 200, 112095. [CrossRef]

45. Sahu, O. Characterisation and utilization of heterogeneous catalyst from waste rice-straw for biodiesel conversion. Fuel 2021, 287, 119543. [CrossRef]

46. Onoji, S.E.; Iyuke, S.E.; Igbafe, A.I.; Daramola, M.O. Transesterification of rubber seed oil to biodiesel over a calcined waste rubber seed shell catalyst: Modeling and optimization of process variables. Energy Fuels 2017, 31, 6109-6119. [CrossRef]

47. Rajkumari, K.; Rokhum, L. A sustainable protocol for production of biodiesel by transesterification of soybean oil using banana trunk ash as a heterogeneous catalyst. Biomass Convers. Biorefin. 2020, 10, 839-848. [CrossRef]

48. Olatundun, E.A.; Borokini, O.O.; Betiku, E. Cocoa pod husk-plantain peel blend as a novel green heterogeneous catalyst for renewable and sustainable honne oil biodiesel synthesis: A case of biowastes-to-wealth. Renew. Energy 2020, 166, 163-175. [CrossRef]

49. Gouran, A.; Aghel, B.; Nasirmanesh, F. Biodiesel production from waste cooking oil using wheat bran ash as a sustainable biomass. Fuel 2021, 295, 120542. [CrossRef]

50. Lathiya, D.R.; Bhatt, D.V.; Maheria, K.C. Synthesis of sulfonated carbon catalyst from waste orange peel for cost effective biodiesel production. Bioresour. Technol. Rep. 2018, 2, 69-76. [CrossRef]

51. Gohain, M.; Laskar, K.; Paul, A.K.; Daimary, N.; Maharana, M.; Goswami, I.K.; Hazarika, A.; Bora, U.; Deka, D. Carica papaya stem: A source of versatile heterogeneous catalyst for biodiesel production and C-C bond formation. Renew. Energy 2020, 147, 541-555. [CrossRef]

52. Betiku, E.; Akintunde, A.M.; Ojumu, T.V. Banana peels as a biobase catalyst for fatty acid methyl esters production using Napoleon's plume (Bauhinia monandra) seed oil: A process parameters optimization study. Energy 2016, 103, 797-806. [CrossRef]

53. Basumatary, S.; Nath, B.; Das, B.; Kalita, P.; Basumatary, B. Utilization of renewable and sustainable basic heterogeneous catalyst from Heteropanax fragrans (Kesseru) for effective synthesis of biodiesel from Jatropha curcas oil. Fuel 2021, 286, 119357. [CrossRef]

54. Uprety, B.K.; Chaiwong, W.; Ewelike, C.; Rakshit, S.K. Biodiesel production using heterogeneous catalysts including wood ash and the importance of enhancing byproduct glycerol purity. Energy Convers. Manag. 2016, 115, 191-199. [CrossRef]

55. Chouhan, A.P.S.; Sarma, A.K. Biodiesel production from Jatropha curcas L. oil using Lemna perpusilla Torrey ash as heterogeneous catalyst. Biomass Bioenergy 2013, 55, 386-389. [CrossRef]

56. Changmai, B.; Sudarsanam, P.; Rokhum, L. Biodiesel production using a renewable mesoporous solid catalyst. Ind. Crop. Prod. 2020, 145, 111911. [CrossRef]

57. Abdelhady, H.H.; Elazab, H.A.; Ewais, E.M.; Saber, M.; El-Deab, M.S. Efficient catalytic production of biodiesel using nano-sized sugar beet agro-industrial waste. Fuel 2020, 261, 116481. [CrossRef]

58. Bastos, R.R.C.; Corrêa, A.P.D.L.; da Luz, P.T.S.; Filho, G.N.D.R.; Zamian, J.R.; da Conceição, L.R.V. Optimization of biodiesel production using sulfonated carbon-based catalyst from an amazon agro-industrial waste. Energy Convers. Manag. 2020, 205, 112457. [CrossRef]

59. Yu, H.; Cao, Y.; Li, H.; Zhao, G.; Zhang, X.; Cheng, S.; Wei, W. An efficient heterogeneous acid catalyst derived from waste ginger straw for biodiesel production. Renew. Energy 2021, 176, 533-542. [CrossRef]

60. Nabora, C.S.; Kingondu, C.K.; Kivevele, T.T. Tamarindus Indica fruit shell ash: A low cost and effective catalyst for biodiesel production from Parinari curatellifolia seeds oil. SN Appl. Sci. 2019, 1, 253. [CrossRef]

61. Kumar, P.; Sarma, A.K.; Bansal, A.; Jha, M.K. Formulation of SrO-MBCUS agglomerates for esterification and transesterification of high FFA vegetable oil. Bull. Chem. React. Eng. Catal. 2016, 11, 140-150. [CrossRef]

62. Sharma, M.; Khan, A.A.; Puri, S.; Tuli, D. Wood ash as a potential heterogeneous catalyst for biodiesel synthesis. Biomass Bioenergy 2012, 41, 94-106. [CrossRef]

63. Li, C.; Hu, X.; Feng, W.; Wu, B.; Wu, K. A supported solid base catalyst synthesized from green biomass ash for biodiesel production. Energy Sources Part A Recover. Util. Environ. Eff. 2017, 40, 142-147. [CrossRef]

64. Adepoju, T.F. Optimization processes of biodiesel production from pig and neem (Azadirachta indica a. Juss) seeds blend oil using alternative catalysts from waste biomass. Ind. Crop. Prod. 2020, 149, 112334. [CrossRef]

65. Betiku, E.; Etim, A.O.; Pereao, O.; Ojumu, T.V. Two-step conversion of neem (Azadirachta indica) seed oil into fatty methyl esters using a heterogeneous biomass-based catalyst: An example of cocoa pod husk. Energy Fuels 2017, 31, 6182-6193. [CrossRef]

66. Dai, Y.-M.; Chen, K.-T.; Wang, P.-H.; Chen, C.-C. Solid-base catalysts for biodiesel production by using silica in agricultural wastes and lithium carbonate. Adv. Powder Technol. 2016, 27, 2432-2438. [CrossRef]

67. Kamel, D.A.; Farag, H.A.; Amin, N.K.; Zatout, A.A.; Fouad, Y.O. Utilization of Ficus carica leaves as a heterogeneous catalyst for production of biodiesel from waste cooking oil. Environ. Sci. Pollut. Res. 2019, 26, 32804-32814. [CrossRef]

68. Kamel, D.A.; Farag, H.A.; Amin, N.K.; Zatout, A.A.; Ali, R.M. Smart utilization of jatropha (Jatropha curcas Linnaeus) seeds for biodiesel production: Optimization and mechanism. Ind. Crop. Prod. 2018, 111, 407-413. [CrossRef]

69. Laskar, I.B.; Rajkumari, K.; Gupta, R.; Chatterjee, S.; Paul, B.; Rokhum, S.L. Waste snail shell derived heterogeneous catalyst for biodiesel production by the transesterification of soybean oil. RSC Adv. 2018, 8, 20131-20142. [CrossRef] 
70. Laskar, I.B.; Gupta, R.; Chatterjee, S.; Vanlalveni, C.; Rokhum, L. Taming waste: Waste Mangifera indica peel as a sustainable catalyst for biodiesel production at room temperature. Renew. Energy 2020, 161, 207-220. [CrossRef]

71. Chen, G.; Shan, R.; Shi, J.; Liu, C.; Yan, B. Biodiesel production from palm oil using active and stable K doped hydroxyapatite catalysts. Energy Convers. Manag. 2015, 98, 463-469. [CrossRef]

72. Lim, B.P.; Maniam, G.P.; Hamid, S. Biodiesel from adsorbed waste oil on spent bleaching clay using $\mathrm{CaO}$ as a heterogeneous catalyst. Eur. J. Sci. Res. 2009, 33, 347-357.

73. Mutreja, V.; Singh, S.; Ali, A. Potassium impregnated nanocrystalline mixed oxides of La and Mg as heterogeneous catalysts for transesterification. Renew. Energy 2014, 62, 226-233. [CrossRef]

74. Xie, W.; Zhao, L. Heterogeneous $\mathrm{CaO}-\mathrm{MoO}_{3}-\mathrm{SBA}-15$ catalysts for biodiesel production from soybean oil. Energy Convers. Manag. 2014, 79, 34-42. [CrossRef]

75. Hussain, F.; Alshahrani, S.; Abbas, M.; Khan, H.; Jamil, A.; Yaqoob, H.; Soudagar, M.; Imran, M.; Ahmad, M.; Munir, M. Waste animal bones as catalysts for biodiesel production; a mini review. Catalysts 2021, 11, 630. [CrossRef]

76. Deka, D.C.; Basumatary, S. High quality biodiesel from yellow oleander (Thevetia peruviana) seed oil. Biomass Bioenergy 2011, 35, 1797-1803. [CrossRef]

77. Sarma, A.K.; Kumar, P.; Aslam, M.; Chouhan, A.P.S. Preparation and characterization of Musa balbisiana Colla underground stem nano-material for biodiesel production under elevated conditions. Catal. Lett. 2014, 144, 1344-1353. [CrossRef]

78. Benefuel, Sustainable Fuel and Chemical Production. Available online: http:/ /www.benefuel.net/ (accessed on 1 October 2021).

79. Biodiesel Magazine. Available online: http://biodieselmagazine.com/articles/3536/a-solid-catalyst-unlike-the-rest/ (accessed on 1 October 2021). 